\title{
Bailiaspis (Trilobita) with English affinities from the Mansilla Formation (Cambrian Series 3 of the Iberian Chains; NE Spain)
}

\author{
Juan B. CHIRIVELLA MARTORELL ${ }^{1}$, Eladio LIÑÁN ${ }^{2}, M^{a}$ Eugenia DIES ÁLVAREZ³, Rodolfo \\ GOZALO ${ }^{4 *}$
}

${ }^{1}$ Departamento de Ciencias de la Educación, Universidad CEU Cardenal Herrera. Avda. Seminario s/n, E-46113 Moncada, Spain; juanchirivella@ieslesfoies.org

${ }^{2}$ Departamento de Ciencias de la Tierra-IUCA. Universidad de Zaragoza, E-50009 Zaragoza, Spain; linan@unizar.es

${ }^{3}$ Departamento de Didáctica de las Ciencias Experimentales-IUCA, Universidad de Zaragoza, C/ Valentín Carderera 4, E-22003Huesca, Spain; medies@unizar.es

${ }^{4}$ Departamento de Botánica y Geología, Universitat de València, C/ Dr. Moliner 50, E-46100- Burjassot, Spain; rodolfo.gozalo@uv.es

* Corresponding author

Chirivella Martorell, J.B., Liñán, E., Dies Álvarez, Ma E., \& Gozalo, R. 2017. Bailiaspis (Trilobita) with English affinities from the Mansilla Formation (Cambrian Series 3 of the Iberian Chains; NE Spain). [Bailiaspis (Trilobita) de afinidad inglesa en la Formación Mansilla (Serie 3 del Cámbrico de la Cadena Ibérica; NE España)]. Spanish Journal of Palaeontology, 32 (1), 17-26.

\section{ABSTRACT}

A new study of the trilobite record in the Mansilla Formation (Iberian Chains, NE Spain) has led to the discovery of the presence of Bailiaspis aff. tuberculata, B. cf. tuberculata and Bailiaspis sp., the first certain citation of this genus in the Mediterranean subprovince. The age of the findings extends from Eccaparadoxides asturianus Zone (upper Leonian) to the lowermost Badulesia tenera Zone (lower Caesaraugustan), which correspond to the upper part of Stage 5 of Cambrian Series 3 and, probably, the lowermost Drumian.

The specimens show the cranidial anterior border expanding backwards, forming a plectrum that is characteristic of Bailiaspis. The main characters of the three taxa include: a low convexity of the cranidium, with a very short or absent preglabellar field, and a cranidial sculpture with numerous densely-packed coarse tubercles. The only species that shows these diagnostic characters is Bailiaspis tuberculata from the middle Cambrian of England (Nuneaton, Warwickshire) in horizons inconclusively dated as the Ptychagnostus gibbus

\section{RESUMEN}

El estudio de del registro de los trilobites de la Formación Mansilla (Cadenas Ibéricas, NE de España) ha permitido reconocer la presencia de Bailiaspis aff. tuberculata, B. cf. tuberculata y Bailiaspis sp., supone la primera cita confirmada de este género en la subprovincia Mediterránea. La edad de los hallazgos se extiende desde la Zona de Eccaparadoxides asturianus (Leoniense superior) a la parte inferior de la Zona de Badulesia tenera (Caesaraugustiense inferior), que se corresponden con la parte superior del piso 5 del Cámbrico y, probablemente, con la parte basal del Drumiense (Serie 3 del Cámbrico).

Los especímenes muestran su borde anterior del cranidio expandido posteriormente, constituyendo un plectrum, que es característico del género Bailiaspis. Los caracteres principales de los tres taxones estudiados son la baja convexidad del cranidio, un área preglabelar reducida o ausente y una ornamentación densa de tubérculos gruesos. La única especie de este género que presenta estos caracteres diagnósticos 
Zone (Cambrian Stage 5). This zone has been previously correlated with the upper Leonian and lower Caesaraugustan; thus, the British and Spanish materials are probably of similar age.

Keywords: Systematic, trilobites, Cambrian Stage 5 and lowermost Drumian (Cambrian Series 3), biostratigraphy. es Bailiaspis tuberculata del Cámbrico medio de Inglaterra (Nuneaton, Warwickshire) procedente de niveles datados con dudas como de la Zona de Ptychagnostus gibbus (Piso 5 del Cámbrico). Esta zona, previamente, ha sido correlacionada con el Leoniense superior y el Caesaraugustiense inferior; por lo que el material británico y español, probablemente, tienen una edad similar.

Palabras clave: Sistemática, Trilobita, Piso 5 del Cámbrico y Drumiense basal (Serie 3 del Cámbrico), bioestratigrafía.

\section{INTRODUCTION}

The traditional middle Cambrian (or provisional Cambrian Series 3) in the Iberian Chains has provided an important record of polymerid trilobites, together with sporadic myomerids (see Liñán et al., 2008; Gozalo et al., 2008). Polymerid trilobites enable fine stratigraphic subdivision of provisional Cambrian Series 2 through Furongian strata on most of the Cambrian palaeocontinents. The polymerids tend to be endemic and intercontinental correlation of these series is hampered by the strong provinciality of the trilobite fauna. Most of the species recorded in the Iberian Chains are endemic to the Mediterranean subprovince (sensu Sdzuy et al., 1999). The problem of correlation is made worse by the scarcity of agnostoids in the Cambrian of the Mediterranean margin of West Gondwana and each new finding of fossils that potentially enables intercontinental correlation merits study and publication. The aim of this paper was to describe a bizarre conocoryphid trilobite from provisional Series 3, Stage 5, in the Iberian Chains. It closely resembles Bailiaspis tuberculata Lake, 1940 that has previously been described from Series 3 in England.

\section{STRATIGRAPHY AND BIOSTRATI- GRAPHY}

The studied material of the Iberian Chains was collected in the upper part of the Mansilla Formation (Liñán et al., 1992, 2002, 2004) in the Villafeliche 1 and Jarque 1 sections (Zaragoza province, NE Spain). Both sections are located within the Badules tectonostratigraphic unit (Fig. 1) (Gozalo \& Liñán, 1988; Liñán et al., 2008).

The Mansilla Formation is made up of alternations of brown dolostones and limestones and purple and violet shales, containing rich assemblages of trilobites, brachiopods, echinoderms, sponges and algae in its upper part. The formation varies in thickness between 10 to 90 meters and its top is slightly diachronic, ranging from the upper part of the Eccaparadoxides asturianus Zone to the lower part of the Badulesia granieri Zone (Fig. 4). However, the material of Bailiaspis is very rare: we have identified more than 500 cranidia at specific level, but we only found 4 cranidia assigned to Bailiapis, less than $1 \%$ of the classified material.

The Mansilla Formation has a thickness of $13.5 \mathrm{~m}$ in the Villafeliche 1 section (see Gozalo et al., 1993, 1996; Fig. 2). We can distinguish two members. The lower member is $5 \mathrm{~m}$ thick and it is composed of nodular and thin-bedded decimetre-thick carbonate levels, these levels become metre-thick beds upwards; shales levels of millimetre or centimetre thickness are intercalated. All of them have red to pink colours. The upper member, $8.5 \mathrm{~m}$ thick, is composed of an alternation of red and violet shales and marls. This member has many scattered carbonate nodules that sometimes become a continuous decimetrethick level. The Mansilla Formation is differentiated from other formations of the Mesones Group (which are mainly green or greyish green) by its reddish colours.

The only specimen of Bailiaspis aff. tuberculata Lake, 1940 was found in the level 1 of this section. The trilobite assemblage recorded at this level is composed of Peronopsis acadica (Hartt in Dawson, 1868), Eccaparadoxides sdzuyi Liñán, 1978, E. asturianus (Sdzuy, 1968), E. sulcatus Liñán \& Gozalo, 1986, Asturiaspis inopinatus Sdzuy, 1968, Parasolenopleura aculeata (Angelin, 1851) [senior synonym of Conocephalites ouangondianus Hartt in Dawson, 1868, sensu Fletcher, 2006], Parabailiella sebarensis Sdzuy, 1968, Parabailiella matutina Sdzuy, 1968 and Holocephalina? leve Gozalo \& Liñán, 1996. The age of this level is Eccaparadoxides asturianus Zone (upper Leonian; see Figs 2 and 4) that has been correlated with the Acadoparadoxides pinus Zone from Baltica (see Sdzuy et al., 1999, fig. 5). Recently, Palacios (2015) analysed several sections with trilobites and acritarchs in the Cantabrian Mountains and proposed the correlation between the Eccaparadoxides asturianus Zone and the Ptychagnostus gibbus Zone.

The Mansilla Formation has a thickness of $72 \mathrm{~m}$ in the Jarque 1 section (see Liñán et al., 1996, 2008; Chirivella Martorell et al., 2003; Fig. 3), where two members are also recognized. The lower member is more carbonate-rich and 


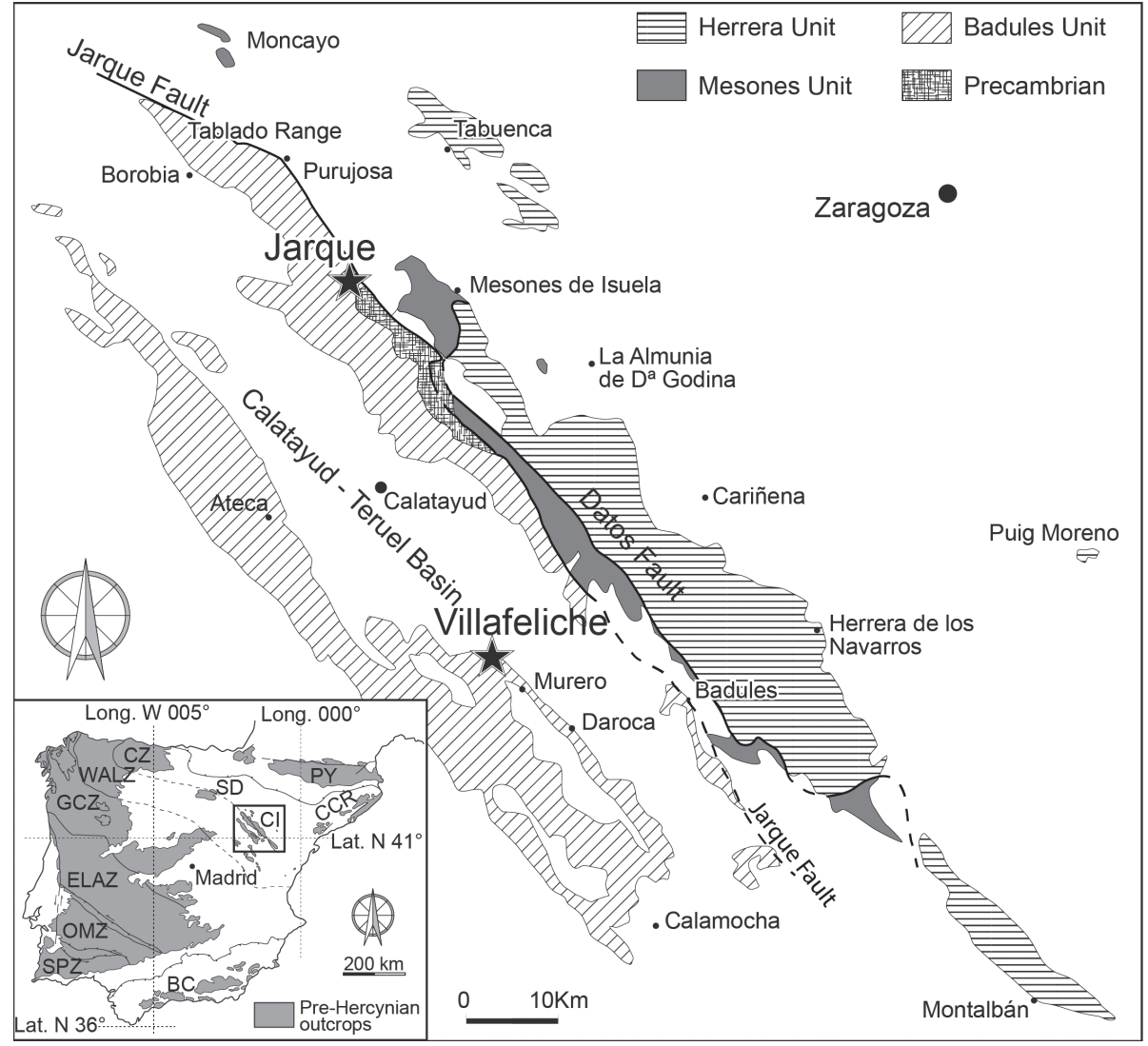

Figure 1. Geological setting of the studied area. The stars indicate the location of studied sections (modified from Gozalo \& Liñán, 1988, and Liñán et al., 2008).

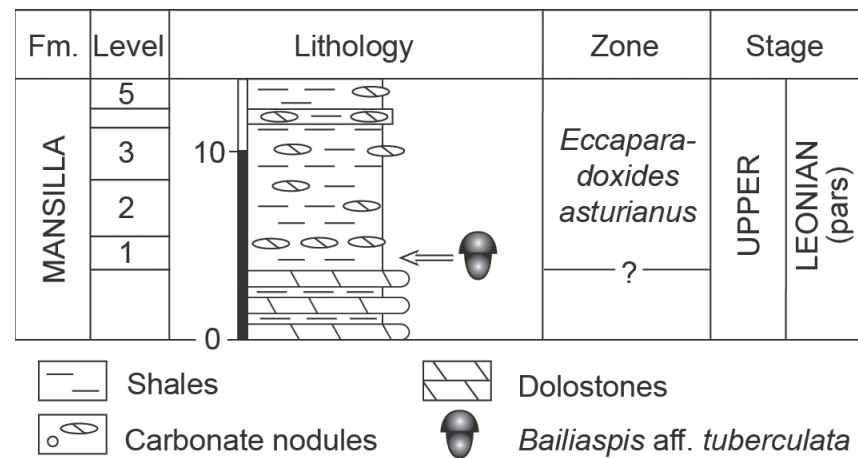

Figure 2. The Mansilla Formation in the Villafeliche 1 (Vi1) section (after Gozalo et al., 1993, 1996).

has a thickness of $26 \mathrm{~m}$. The first $2 \mathrm{~m}$ are composed by violet shales with abundant carbonate nodules and marly dolomites; this part constitutes the transition levels with the underlying Valdemiedes Formation. The next 24 meters are mainly composed of purplish nodular dolomitic levels, with interbedded violet shales and loamy dolostones. The upper member, has a thickness of $46 \mathrm{~m}$ thick, is composed of violet shales with scattered dolomitic nodules, which occasionally constitute a dolomitic level.

The specimens of Bailiaspis Resser, 1936 have been found at levels 156 and 159 of this section. Bailiaspis cf. tuberculata Lake, 1940 was recorded at level 156, the trilobites recorded at this level are: Peronopsis acadica (Hartt in Dawson, 1868), Condylopyge sp., Eccaparadoxides sdzuyi Liñán, 1978, E. asturianus (Sdzuy, 1968), Asturiaspis inopinatus Sdzuy, 1968, Parabailiella sebarensis Sdzuy,1968, Parabailiella languedocensis Thoral, 1946, Parabailiella matutina Sdzuy, 1968, Parabailiella schmidti Sdzuy, 1957 and Badulesia tenera (Hartt in Dawson, 1868). Bailiaspis sp. was recorded in the level 159 of the Jarque 1 together with Parabailiella schmidti Sdzuy, 1957, Badulesia tenera (Hartt in Dawson, 1868) and Eccaparadoxides sp. The age of both levels is the Badulesia tenera Zone (lower Caesaraugustan; see Figs 3 and 4) that has been correlated with the Ptychagnostus gibbus Zone (see Sdzuy et al., 1999; fig. 5). Palacios (2015; fig. 3) identified the boundary between his IMC1 and IMC2 acritarch Zones in a level near the base of the Badulesia tenera Zone in the Porma section. This author correlates the boundary between both acritarch Zones with the base of the Tomagnostus fissus Zone, that is considered as Drumian. In accordance with the new data provided by Palacios (2015), the upper Leonian and the lowermost Caesaraugustan would be correlated with the Stage 5 of Cambrian and the rest of the lower Caesaraugustan would be correlated with the Drumian stage.

Our new specimens have a very similar morphology to Bailiapis tuberculata Lake, 1940 although, all of them 


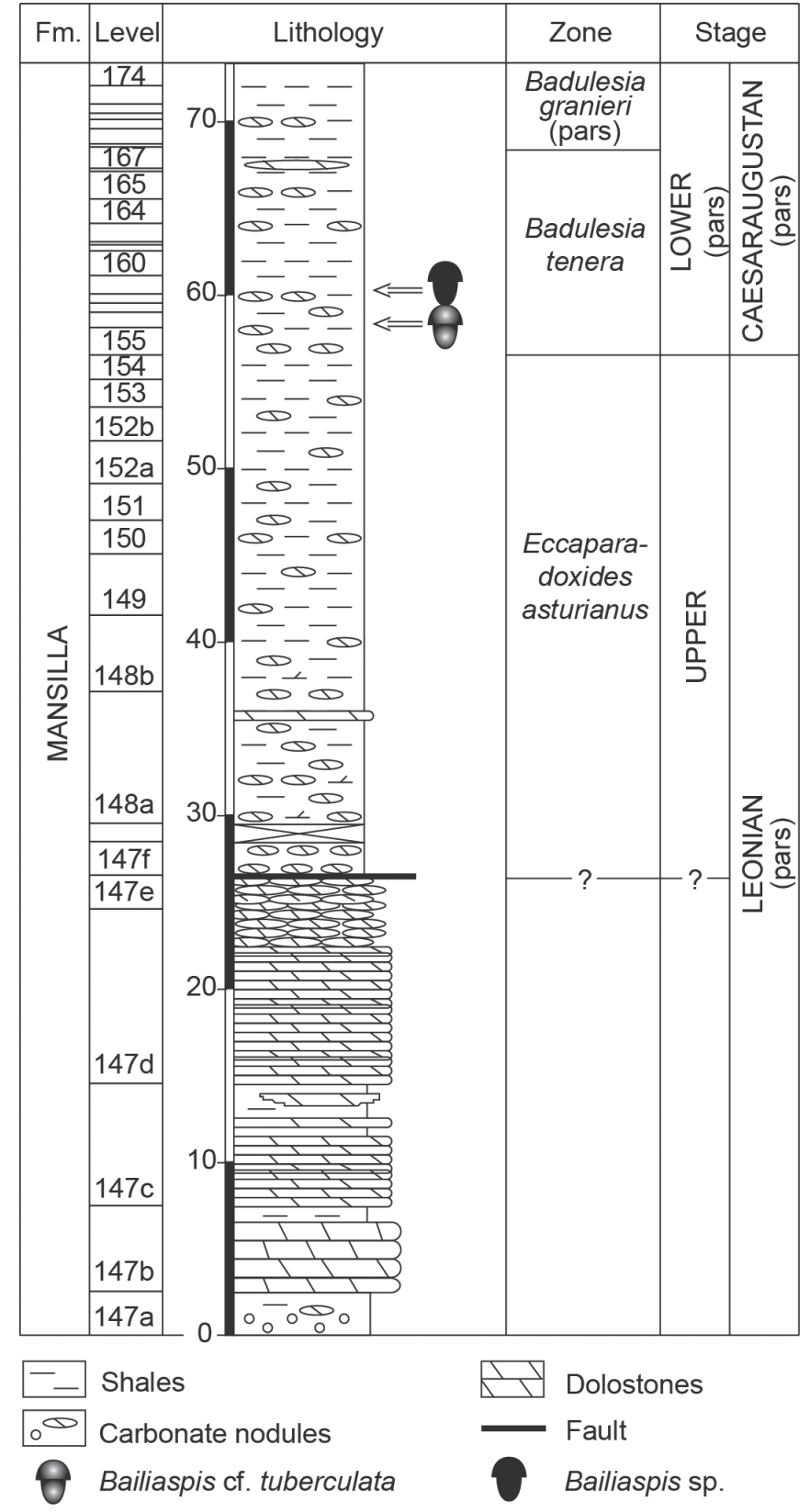

are bigger than the English specimens. This species was recorded from level A4 in the Abbey Shales Formation, in the Paradoxides aurora Zone sensu Illing (1916), which level is assigned with uncertainty to the Ptychagnostus gibbus Zone (see Rushton, 1979, 1999, 2011; Rees et al., 2014). Rushton (1979) studied the agnostoid fauna published by Illing (1916) including level A4, where Bailiaspis tuberculata Lake, 1940 had been found. Condylopyge rex (Barrande, 1846) was recorded together at the same level (Illing, 1916; Rushton, 1979). This species has a long biostratigraphic range in the Iberian Chains beginning at the base of the Pardailhania hispida Zone (middle Caesaraugustan), following Gozalo et al. (2011). Although cephala of Condylopyge sp. have also been found in the lower Caesaraugustan, the lack of pygidia prevents specific identification. On the other hand, the biostratigraphic range of Paradoxides aurora Salter in Salter \& Hicks, 1869 coincides approximately with the Ptychagnostus gibbus Zone in England (see Thomas et al., 1984, fig. 3).

Previously, Sdzuy et al. (1999, fig. 5) and Gozalo et al. (2007, fig. 6) correlated the Acadoparadoxides oelandicus Stage with the Leonian Stage and Ptychagnostus gibbus Zone with Badulesia tenera Zone (lower Caesaraugustan). The new data provided by Palacios (2015) show that only the base of Badulesia tenera Zone is correlated with the top of Ptychagnostus gibbus zone, and the rest of the Badulesia tenera zone is correlated with the Tomagnostus fissus Zone, that is Drumian in age (see Fig. 4). In this figure, we propose a tentative correlation chart between the Iberian Chains and the Nuneaton successions where the fossils from the base of the Abbey Shale Formation would be correlated with the Badulesia tenera Zone in accordance with the previous correlation chart and the new acritarch data.

Figure 3. The Mansilla Formation in the Jarque 1 (J1) section (after Liñán et al., 1996, 2008).

\begin{tabular}{|c|c|c|c|c|c|c|}
\hline \multicolumn{3}{|c|}{$\begin{array}{c}\text { IBERIA } \\
\text { (Iberian Chains) }\end{array}$} & \multicolumn{2}{|c|}{$\begin{array}{l}\text { ENGLAND } \\
\text { (Nuneaton) }\end{array}$} & \multicolumn{2}{|c|}{ GLOBAL } \\
\hline Formations & Zone & St. & Formations & Zone & Stage & \\
\hline \multirow[t]{2}{*}{$\begin{array}{c}\text { Murero } \\
\text { (pars) }\end{array}$} & $\begin{array}{c}\text { Badulesia } \\
\text { granieri }\end{array}$ & $\begin{array}{l}z \\
5 \\
0 \\
0 \\
0 \\
\frac{1}{\alpha} \\
\frac{1}{\alpha}\end{array}$ & \multirow{3}{*}{$\begin{array}{l}\text { Abbey } \\
\text { shales } \\
\text { (pars) }\end{array}$} & \multirow[t]{2}{*}{$\begin{array}{l}\text { fissus } \\
\text { (pars) }\end{array}$} & \multirow[t]{2}{*}{$\begin{array}{c}\text { Drumian } \\
\text { (pars) }\end{array}$} & \multirow{4}{*}{ 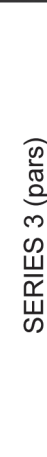 } \\
\hline & $\begin{array}{c}\text { Badulesia } \\
\text { tenera }\end{array}$ & $\begin{array}{l}\text { 岩 } \\
\text { 足 } \\
\text { 岁 }\end{array}$ & & & & \\
\hline $\begin{array}{l}\text { B.sp. } \\
\text { B.cf.t. }\end{array}$ & & 오 & & \multirow[b]{2}{*}{ gibbus? } & \multirow[b]{2}{*}{$\begin{array}{c}\text { Stage } 5 \\
\text { (pars) }\end{array}$} & \\
\hline (pars) & $\begin{array}{c}\text { Eccaparado- } \\
\text { xides } \\
\text { asturianus }\end{array}$ & 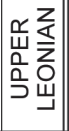 & $\begin{array}{c}\text { Purley shales } \\
\text { (pars) }\end{array}$ & & & \\
\hline
\end{tabular}

Figure 4. Bailiaspis tuberculata Lake, 1940 (B.t.) distribution and related taxa (B.sp.; B.cf.t.; B.aff.t.). Biostratigraphical sketch from Iberia sensu Sdzuy et al. (1999), Gozalo et al. (2011) and Palacios (2015); data form Nuneaton (England) referred by Rushton (2011, figs. 11, 12), and their comparison with the global proposals of International Subcommission on Cambrian Stratigraphy (Peng \& Babcock, 2011). 


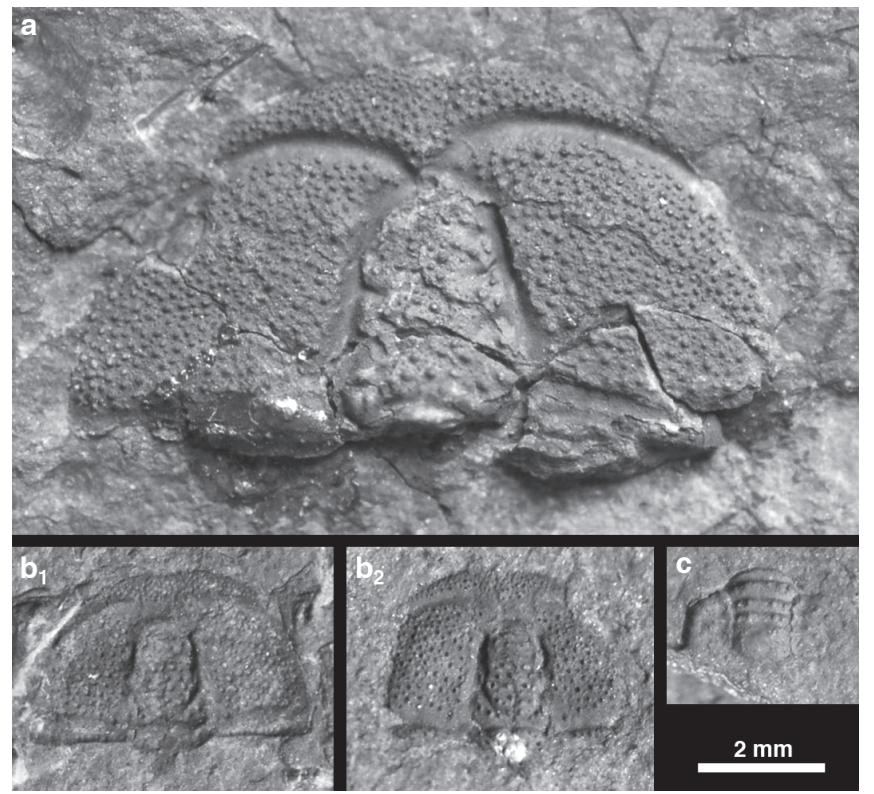

Figure 5. Type material of Bailiaspis tuberculata Lake, 1940 from level A4 to the Abbey Shales Formation in the Paradoxides aurora Zone (Nuneaton, Warwickshire, England). a) Cranidium, internal mould, Holotype, A15633 Sedgwick Museum. b) Small cranidium, A224 Sedgwick Museum, (b1) internal mould, (b2) external mould. c) Pygidium, internal mould, A15634 Sedgwick Museum. The magnification of the specimen A15633 figured by Illing (1916, pl. XXXV fig. 2) must be $\mathrm{x} 2.5$, there is a small mistake in the legend of the plate.

\section{SYSTEMATIC DESCRIPTION}

\author{
Class TRILOBITA Walch, 1771
}

Order PTYCHOPARIIDA Swinnerton, 1915

Suborder PTYCHOPARIINA Richter, 1932

Superfamily Ptychoparioidea Matthew, 1888

Family Conocoryphidae Angelin, 1854

Genus Bailiaspis Resser, 1936

Type species: Conocephalites elegans Hartt in Dawson, 1868 by original designation.

Remarks. Kim et al. (2002) provided a discussion of genus Bailiaspis Resser, 1936 that we follow here.

Bailiaspis has been cited previously in the Iberian Chains in two different formations. Bailiaspis meridiana Sdzuy, 1958 (see also Sdzuy, 1961); and Bailiaspis aff. meridiana Sdzuy, 1958 sensu Liñán \& Gozalo, 1986 from the Murero Formation (middle Caesaraugustan, equivalent to the Drumian, see Gozalo et al., 2011); and Bailiaspis ? glabrata (Angelin, 1854) from the Valtorres Formation (Guzhangian, see Álvaro et al., 2013). The two former species have been transferred to Bailiella Matthew, 1885 by Kim et al. (2002) and the third is assigned, though with uncertainty, to Bailiaspis, although previously was tentatively assigned to Bailiella (see Sdzuy, 1966; Korobov, 1973). In the phylogenetic analysis carried out by Cotton (2001), B. glabrata appears consistently close to Bailiella levyi (Munier-Chalmas \& Bergeron in Bergeron, 1889) and always outside the main node where other Bailiaspis species are located. Thus, the presence of Bailiaspis in the Iberian Chains, until now, remained uncertain.

The new specimens found in the Mansilla Formation (upper Leonian and lower Caesaraugustan) show the diagnostic character of genus Bailiaspis. They show a true Bailiapis plectrum, i.e., the anterior border expands backwards and the anterior border furrow is bowed sharply posteriorly (Westergård, 1950; Kim et al., 2002). Also, the only species described with cranidial sculpture formed by densely-packed coarse tubercles is Bailiaspis tuberculata Lake, 1940 (see Fig. 5). However, the scarcity of material and the morphological differences among the studied specimens, which have been found in different levels, prevent us from considering all of them as only one taxon, presumably united by the sculpture of closely set tubercles, and we prefer to describe them as three taxa in open nomenclature waiting to know the intraspecific variation of $B$. tuberculata by means of new discoveries.

\section{Bailiaspis cf. tuberculata Lake, 1940}

Figs 6a-6b

Material. Two cranidia preserved as external and internal moulds in red dolomitic marls and blue-grey shales. Housed in the Museo de Ciencias Naturales de la Universidad de Zaragoza - formerly known (until 2012) as Museo Paleontológico de la Universidad de Zaragoza, Spain -, registered with numbers MPZ 2007/1394 and 2007/1395.

Description. Cranidium slightly convex and semielliptical in outline, with length about half the width. Forwardly tapered, bluntly rounded glabella with width at anterior about 50 percent of width at occipital furrow; axial furrows well incised and preglabellar furrow somewhat shallower. Three pairs of lateral glabellar furrows present: S1 long, directed obliquely backwards and extending a third across glabella; S2 short and oblique; S3 very short and subtransverse. Shallow occipital furrow, subtransverse medially, but curved forward distally. Occipital ring occupies about 15 percent of cranidial length. Frontal area occupies about 30 percent of cranidial length and has gently curved posterior margin. Preglabellar field very short or absent, with anterior border furrow and preglabellar furrow confluent. Anterior border thickening sag. (see Figs $6 \mathrm{a} 3$ and $6 \mathrm{~b} 1$ ), convex with plectrum, and narrows distally. Anterior border furrow is shallow but 


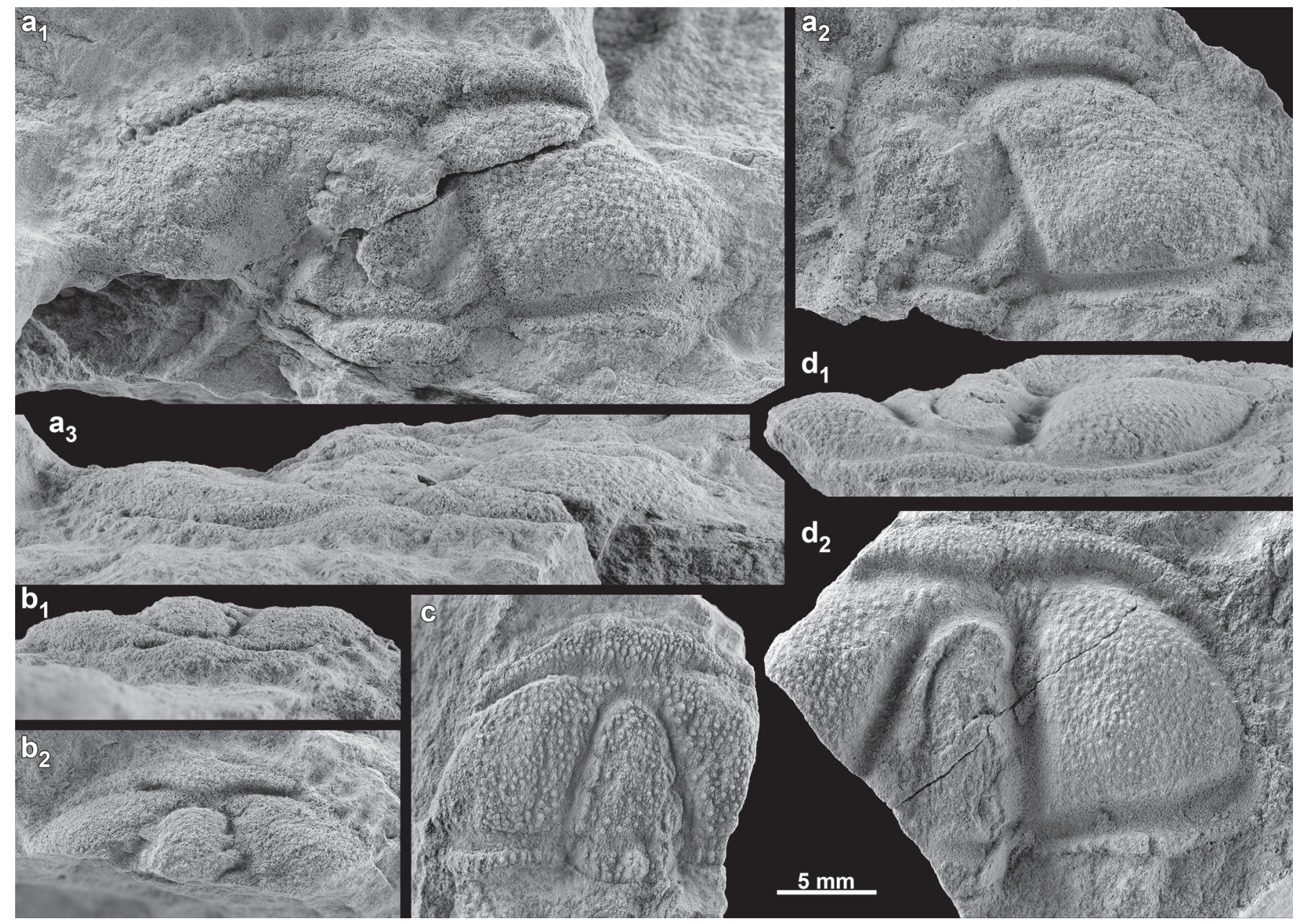

Figure 6. Bailiaspis from the Iberian Chains. a) Bailiaspis cf. tuberculata Lake, 1940 cranidium, level 156, Jarque 1 section, MPZ 2007/1394; (a1) internal mould; (a2) latex cast of the same specimen; (a3) anterior view of the internal mould. b) Bailiaspis cf. tuberculata Lake, 1940 cranidium internal mould, level 156, Jarque 1 section, MPZ 2007/1396; (b1) anterior and (b2) dorsal views. c) Bailiaspis sp. cranidium internal mould, level 159 Jarque 1 section, MPZ 2007/1395. d) Bailiaspis aff. tuberculata Lake, 1940 cranidium internal mould, level 1, Villafeliche 1 section, MPZ 2007/1397; (d1) anterior and (d2) dorsal views.

clearly defined and curved forward. Fixigenae convex. Posterior border furrow is broad, shallow groove; posterior border narrow near axial furrow but widens distally. Facial sutures intersect lateral border and furrow. Sculpture on all surfaces except furrows include numerous densely-packed coarse tubercles.

Remarks. Kim et al. (2002; p. 830-831) compared the different species assigned to Bailiaspis Resser, 1936 in the discussion of Bailiaspis venusta Resser, 1937. They stated that the main difference between Bailiaspis tuberculata Lake, 1940 and other species of the genus is the cranidial sculpture. The specimens found in the Jarque Section show this characteristic cranidial ornamentation. Furthermore, the preglabellar area is either absent or reduced sagittally to a slim line, a character also found in the English specimens. Finally, the percentage of the cranidium length, compared with the frontal area and occipital ring lengths, are the same in both English and Spanish specimens. These coincidences in the diagnostic characters of both type and newly found material lead us to consider that they might belong to the same species, but their poor condition and difference in size prevents this specific assignation.

Stratigraphic distribution. The specimens were found in level 156 of the Jarque 1 Section (Fig. 3), Badulesia tenera Zone base (lower Caesaraugustan Stage), equivalent to the top of Stage 5 of the Cambrian System (see Fig. 4).

Bailiaspis aff. tuberculata Lake, 1940

Fig. 6d

Material. One cranidium preserved as an internal mould in blue-grey shales. Housed in the Museo de Ciencias Naturales de la Universidad de Zaragoza with acronym MPZ 2007/1397. 
Description. Cranidium slightly convex and semielliptical in outline, with length about $2 / 3$ of the width. Forwardly tapered, bluntly rounded glabella with width at anterior about 50 percent of estimated width at occipital furrow; axial furrows well incised and preglabellar furrow somewhat shallower. Three pairs of lateral glabellar furrows present, but the surface of the glabella is badly preserved. Occipital furrow, shallow. Occipital ring occupies about 20 percent of the glabellar length. Frontal area occupies about 25 percent of the cranidial length. Preglabellar field slender, which is crossed by two rows of tubercles. Anterior border slightly thicker (see Fig. 6d1) with weakly developed plectrum, and narrows distally; anterior border furrow shallow but clearly defined. Fixigenae convex. Posterior border furrow is broad, shallow groove; posterior border narrow near axial furrow but widens distally. Facial sutures intersect the lateral border and furrow which is very thin and does not intersect the fixigenae. Sculpture on all surfaces except furrows include numerous denselypacked coarse tubercles.

Remarks. The specimen found in Villafeliche shows a morphology close to that of Bailiaspis tuberculata Lake, 1940. But Bailiaspis aff. tuberculata Lake, 1940 presents a narrower preglabellar area and has a more pronounced plectrum. This character prevents us from including the specimen in B. tuberculata, despite the similar cranidial sculpture, and we prefer to classify it in open nomenclature.

Rushton (1966; p. 45) described Bailiaspis sp. from the top of the Purley shales Formation, just below of the type level of Bailiaspis tuberculata. The cranidium morphology of Bailiaspis sp. and Bailiaspis aff. tuberculata are very close and with a similar percentages of length occupied by the occipital ring and frontal area. The main difference is the ornamentation composed of fine granules and sparse scattering of large tubercles in the English specimen.

Stratigraphic distribution. The specimen was found in level 1 of the Villafeliche 1 Section, Eccaparadoxides asturianus Zone (upper Leonian Stage), equivalent to the upper part of Stage 5 of Cambrian (see Fig. 4)

\section{Bailiaspis sp.}

Fig. 6c

Material. One cranidium preserved as an internal mould in green-grey shales. Housed in the Museo de Ciencias Naturales de la Universidad de Zaragoza under the number MPZ 2007/1396.

Description. Cranidium semielliptical in outline. Forwardly tapered, bluntly rounded glabella with width at anterior about 50 percent of width at occipital furrow; axial furrows well incised and preglabellar furrow somewhat shallower. Three pairs of lateral glabellar furrows present, but the surface of the glabella is badly preserved. Occipital furrow, shallow. Occipital ring occupies about 20 percent of the glabellar length. Frontal area occupies about 30 percent of the cranidial length. Preglabellar field slender, which is crossed by one row of tubercles. Anterior border slightly convex with short plectrum; anterior border furrow shallow but clearly defined and curved forward. Fixigenae slightly convex. Broad posterior border furrow, shallow groove; narrow posterior border near the axial furrow but widens distally. The facial sutures intersect the lateral border and furrow. This is very thin and the facial suture does not intersect the fixigenae. The sculpture is present on all surfaces except furrows and include numerous denselypacked coarse tubercles.

Remarks. The morphological characteristics of the specimen found in Jarque level 159, allows its classification in the genus, this specimen shows a morphology close to the juvenile specimen of Bailiaspis tuberculata Lake, 1940. But the specimen of Bailiaspis sp. is much bigger than the English specimen. This character prevents us from including the specimen in $B$. tuberculata, despite the similar cranidial sculpture, and we prefer to classify it in open nomenclature.

Stratigraphic distribution. The specimen was found in level 159 of the Jarque 1 Section (Fig. 3), lower part of Badulesia tenera Zone (lower Caesaraugustan Stage), equivalent to the top of Stage 5 of the Cambrian or base of the Drumian stage (see Fig. 4).

\section{CONCLUSIONS}

Diverse stratigraphical sections of the Mansilla Formation have been studied. Two of them contain the trilobites Bailiaspis aff. tuberculata, B. cf. tuberculata and Bailiaspis sp. These are the first confirmed record of genus Bailiaspis in the Iberian Chains and in the Mediterranean subprovince considering that the previous Bailiaspis cited had either been rejected or considered doubtful.

Bailiaspis aff. tuberculata was found in the Eccaparadoxides asturianus Zone (upper Leonian) and has been roughly compared with the Bailiaspis sp. found at the top of the Purley Shales Formation (Rushton, 1966). While the specimens of Bailiaspis cf. tuberculata and Bailiaspis sp. recorded in the Badulesia tenera Zone (lower Caesaraugustan) have been compared with Bailiaspis tuberculata Lake, 1940 of the Paradoxides aurora Zone at the base of the Abbey Shale Formation (see Rushton, 1979, 1999, 2011).

Therefore the biostratigraphic distribution of Paradoxides aurora belongs to Ptychagnostus gibbus Zone sensu Thomas et al. (1984) and the level with 
Bailiaspis tuberculata has been dated with uncertainty as the Ptychagnostus gibbus Zone.

Figure 4 shows a tentative correlation chart between the materials of the Nuneaton area (England) and the Iberian Chains (NE Spain) where we propose the correlation of the top of Purley Shales with the upper Leonian and/or the base of lower Caesaraugustan, while the base of Abbey Shales would be correlated with the lower Caesaraugustan.

\section{ACKNOWLEDGEMENTS}

This is a contribution to the E17 Research Group of the Autonomous Government of Aragón. We thank Dr A. W. A. Rushton (Natural History Museum, London) and Dr I. Rábano (Museo Geominero, IGME, Madrid) who provided constructive reviews. We also want to remark our thanks to Ms Isabel Pérez Urresti who assisted us with the figures and photographs, to Mr Matt Riley (Collections Assistant in Palaeontology of The Sedgwick Museum of Earth Sciences) who provided photographs of the type material of Bailiaspis tuberculata Lake, 1940, and Mr Richard Stephenson for the English revision.

The authors want to acknowledge Professor Pascual Rivas for his essential role in the development of the Sociedad Española de Paleontología.

\section{REFERENCES}

Álvaro, J.J., Zamora, S., Vizcaino, D. \& Ahlberg, P. 2013. Guzhangian (mid Cambrian) trilobites from siliceous concretions of the Valtorres Formation, Iberian Chains, NE Spain. Geological Magazine, 150, 123-142; doi: 10.1017/ S0016756812000416.

Angelin, N.P. 1851. Palceontologia Svecica. Pars I; Iconographia Crustaceorum Formationis Transitionis. Academie Regiae Scientarium Suecanae, Fasc. 1, 1-24, Holmiæ (Stockolm).

Angelin, N.P. 1854. Palceontologia Scandinavica. Pars II; Crustacea Formationis Transitionis. Academie Regiae Scientarium Suecanae, Fasc. 2, I-IX, 21-92, Holmiæ (Stockolm).

Barrande, J. 1846. Notice Préliminaire sur le Système Silurien et les Trilobites de Bohême. Hirschfeld, Leipzig, vi+96 pp.

Bergeron, J. 1889. Étude géologique du Massif ancien situé au Sud du Plateau Central. Annales des Sciences Géologique, 22, IV+361 pp.

Chirivella Martorell, J.B., Gozalo, R. \& Liñán, E. 2003. Estudio taxonómico y biométrico de Badulesia tenera (Hartt in Dawson, 1868), Trilobita. Caesaraugustiense
(Cámbrico Medio) de las Cadenas Ibéricas (NE de España). Revista Española de Paleontología, 18, 83-101.

Cotton, T.J. 2001. The phylogeny and systematics of blind Cambrian ptychoparioid Trilobites. Palaeontology, 44, 167-207; doi: 10.1111/1475-4983.00176.

Dawson, J.W. 1868. Acadian Geology. The Geological Structure, Organic Remains and Mineral Resources of Nova Scotia, New Brunswick, and Prince Edward Island. Macmillan, $2^{\text {nd }}$ ed., London, xxvi+694 pp.

Fletcher, T.P. 2006. Bedrock geology of the Cape St. Mary's Peninsula, southwest Avalon Peninsula, Newfoundland (includes parts of NTS maps sheets 1M/1, 1N/4, 1L/6 and $1 \mathrm{~K} / 13$ ), Newfoundland. Government of Newfoundland and Labrador, Geological Survey, Department of Natural Resources Report 06-02, 1-117.

Gozalo, R. \& Liñán, E. 1988. Los materiales hercínicos de la Cordillera Ibérica en el contexto del Macizo Ibérico. Estudios geológicos, 44, 399-404.

Gozalo, R. \& Liñán, E. 1996. Nueva especie de Conocoryphidae (Trilobita). Cámbrico Medio de las Cadenas Ibéricas (NE de España). Revista Española de Paleontología, 11, 247250.

Gozalo, R., Liñán, E. \& Álvaro, J. 1993. Bioestratigrafía del Cámbrico Medio de Villafeliche (Prov. Zaragoza, España). Revista Española de Paleontología, $\mathrm{n}^{\circ}$ Extra, 49-57.

Gozalo, R., Liñán, E. \& Sdzuy, K. 1996. The Lower and Middle Cambrian of Murero and Villafeliche (West Asturian-Leonese Zone. Western Iberian Chain). In: II Field Conference of the Cambrian Stage Subdivision Working Groups. International Subcommission on Cambrian Stratigraphy. Spain, 13-21 September 1996. Field Trip Guide and Abstracts (eds Liñán, E., Gámez Vintaned, J.A., \& Gozalo, R.). Universidad de Zaragoza, 73-80.

Gozalo, R., Liñán, E., Dies Álvarez, M.E., Gámez Vintaned, J.A. \& Mayoral, E. 2007. The Lower-Middle Cambrian boundary in the Mediterranean subprovince. Geological Society of America Special Paper, 423, 359-373; doi: 10.1130/2007.2423(17).

Gozalo, R., Liñán, E., Gámez Vintaned, J.A., Dies Álvarez, M.E., Chirivella Martorell, J.B., Zamora, S., Esteve, J. \& Mayoral, E. 2008. The Cambrian of the Cadenas Ibéricas (NE Spain) and its trilobites. Cuadernos del Museo Geominero, 9, 137-151.

Gozalo, R., Chirivella Martorell, J.B., Esteve, J. \& Liñán, E. 2011. Correlation between the base of Drumian Stage and the base of middle Caesaraugusan Stage in the Iberian Chains (NE Spain). Bulletin of Geosciences, 86, 545-554; doi: 10.3140/bull.geosci.1254.

Illing, V.C. 1916. The paradoxidian fauna of a part of the Stockingford Shales. Quarterly Journal of the Geological Society, London, 71, year 1915, 386-450.

Kim, D.H., Westrop, S.R. \& Landing, E. 2002. Middle Cambrian (Acadian series) conocoryphid and paradoxidid trilobites from the Upper Chamberlain's Brook Formation, Newfounland and New Brunswick. Journal of Paleontology, 76, 822-842. doi: 10.1017/ S0022336000037501. 
Korobov, M.N. 1973. Trilobites of the Conocoryphidae family and their importance for the stratigraphy of Cambrian deposits. Transactions of the Academy of Science of the USSR, geological Institute, 211, 1-176 (in Russian).

Lake, P.H. 1940. A Monograph of the British Cambrian Trilobites. Palaeontographical Society, London, 273-306.

Liñán, E. 1978. Bioestratigrafía de la Sierra de Córdoba. Tesis Doctorales de la Universidad de Granada, 191, 1-212.

Liñán, E. \& Gozalo, R. 1986. Trilobites del Cámbrico Inferior y Medio de Murero (Cordillera Ibérica). Memorias del Museo Paleontológico de la Universidad de Zaragoza, 2, 1-104.

Liñán, E., Gozalo, R., Gámez Vintaned, J.A. \& Álvaro, J.J. 1992. Las formaciones del Grupo Mesones (Cámbrico Inferior-Medio) en las Cadenas Ibéricas. III Congreso Geológico de España y VIII Congreso Latinoamericano de Geología, Salamanca, Actas 1, 517-523.

Liñán, E., Sdzuy, K., Álvaro, J.J., Gámez Vintaned, J.A. \& Gozalo, R. 1996. The Jarque section: Lower and Middle Cambrian (West Asturian-Leonese Zone. Eastern Iberian Chain. In: II Field Conference of the Cambrian Stage Subdivision Working Groups. International Subcommission on Cambrian Stratigraphy. Spain, 13-21 September 1996. Field Trip Guide and Abstracts (eds Liñán, E., Gámez Vintaned, J.A., \& Gozalo, R.). Universidad de Zaragoza, 57-72.

Liñán, E., Gozalo, R., Palacios, T., Gámez Vintaned, J.A., Ugidos, J.M. \& Mayoral, E. 2002. Cambrian. In: The Geology of Spain (eds Gibbons, W. \& Moreno, T.). The Geological Society, London, 17-29.

Liñán, E., Perejón, A., Gozalo, R., Moreno-Eiris, E. \& Oliveira, J.T. 2004. The Cambrian System in Iberia. Cuadernos del Museo Geominero, 3, 1-63.

Liñán, E., Gozalo, R., Dies Álvarez, M.E., Gámez Vintaned, J.A., Mayoral, E., Chirivella Martorell, J.B., Esteve, J., Zamora, S., Zhuravlev, Yu, A., Andrés, J.A. 2008. Fourth International Trilobite Conference Trilo 08 Toledo, Spain, 2008. Post-Conference Field Trip. Lower and Middle Cambrian trilobites of selected localities in Cadenas Ibéricas (NE Spain). Universidad de Zaragoza, $52 \mathrm{pp}$.

Matthew, G. F. 1885. Illustrations of the fauna of the St. John Group, continued: On the Conocoryphea, with further remarks on Paradoxides. Transactions of the Royal Society of Canada, section 4, 2 (1884), 9-124

Matthew, G. F. 1888. Illustrations of the Fauna of the St. John Group. No. IV.- Part I. Description of a new species of Paradoxides (Paradoxides regina). Part II. The smaller trilobites with eyes (Ptychoparidæ and Ellipsocephalidæ). Transactions of the Royal Society of Canada, section 4, 5, (1887), 115-166.

Palacios, T. 2015. Acritarch assemblages from the Oville and Barrios Formations, northern Spain: A pilot proposal of a middle Cambrian (Series 3) acritarch biozonation in northwestern Gondwana. Review of Palaeobotany and Palynology, 219, 71-105; doi: 10.1016/j.revpalbo.2015.03.008.
Peng, S.C. \& Babcock, L.E. 2011. Continuing progress on chronostratigraphic subdivision of the Cambrian System. Bulletin of Geosciences, 86, 391-396; doi: 10.3140/bull. geosci.1273.

Rees, A.J., Thomas, A.T., Lewis, M., Hughes, H.E. \& Turner, P. 2014. The Cambrian of SW Wales. Towards a united Avalonian Stratigraphy. Geological Society, London, Memoir, 42, 1-139; doi: 10.1144/M42.1.

Resser, C.E. 1936. Second contribution to nomenclature of Cambrian trilobites. Smithsonian Miscellaneous Collections, 95, 1-29.

Resser, C.E. 1937. New species of Cambrian trilobites of the family Conocoryphidae. Journal of Paleontology, $11,39-42$.

Richter, R. 1932. Crustacea (Paläontologie). In: Handwörterbuch der Naturwissenschaften, 2nd ed. (eds Dittler, R., Joos, G., Korschelt, E., Linek, G., Oltmanns, F. \& Schaum, K.). Gustav Fisher, Jena, 840-864.

Rushton, A.W.A. 1966. The Cambrian Trilobites from the Purley Shales of Warwickshire. Monograph of the Palaeontographical Society, London, 511, 1-55.

Rushton, A.W.A. 1979. A review of the Middle Cambrian Agnostida from the Abbey Shales, England. Alcheringa, 3, 43-61; doi: 10.1080/03115517908565439.

Rushton, A.W.A. 1999. Cambrian rocks of England. In: British Cambrian to Ordovician Stratigraphy (eds Rushton, A.W.A., Owen, A.W., Owens, R.M. \& Prigmore, J.K.). Geological conservation Reviews Series. The Joint Nature Conservation Committee, 18, Peterborough, 69-87.

Rushton, A.W.A. 2011. Midland microcraton. In: A Revised Correlation of the Cambrian Rocks in the British Isles (eds Rushton, A.W.A., Brück, P.M., Molyneux, S.G., Williams, M. \& Woodcock, N.H.). Geological Society of London, Special Report 25, 28-34.

Salter, J.W. \& Hicks, H. 1869. On some fossils from the "Menevian Group". Quaterly Journal of the Geological Society of London, 25, 51-57.

Sdzuy, K. 1957. Revision der mittelkambrischen Trilobiten von Doberlug. Senckenbergiana lethaea, 38, 7-28.

Sdzuy, K. 1958. Neue Trilobiten aus dem Mittelkambrium von Spanien. Senckenbergiana lethaea, 39, 235-253.

Sdzuy, K. 1961. Das Kambrium Spanien. Teil II: Trilobites. Akademie der Wissenschaften und der Literatur, Abhandlungen der mathematisch-naturwissenschaftlichen Klasse, 1961, 217-408.

Sdzuy, K. 1966. Das Kambrium des Frankenwaldes. 2. Die Bergleshof-Schichten und ihre Trilobiten-Fauna. Senckenbergiana lethaea, 47, 57-86.

Sdzuy, K. 1968. Trilobites del Cámbrico Medio de Asturias. Trabajos de Geología, Universidad de Oviedo, 1, año 1967, 77-133.

Sdzuy, K., Liñán, E. \& Gozalo, R. 1999. The Leonian Stage (early Middle Cambrian): a unit for Cambrian correlation in the Mediterranean subprovince. Geological Magazine, 136, 39-48; doi: 10.1017/S0016756899002241.

Swinnerton, H.H. 1915. Suggestions for a revised classification of trilobites. Geological Magazine, new series, 6, 487-496, 538-545. 
Thomas, A.T., Owens, R.M. \& Rushton, A.W.A. 1984. Trilobites in British stratigraphy. Geological Society of London, Special Report, 16, 1-78.

Thoral, M. 1946. Conocoryphidae Languedociens. Annales de l'Université de Lyon, sér. 3, section C, Sci. natur. 4, 1-74.

Walch, J.E.I. 1771. Die Naturgeschichte der Versteinerungen zur erläuterung der Knorrischen Sammlung von
Merkwürdigkeiten der Natur. Felßecker, Nürnberg, X + 1-235.

Westergård, A.H. 1950. Non-agnostidean Trilobites of the Middle Cambrian of Sweden. II. Sveriges Geologiska Undersökning, C 511, 1-57. 